\title{
Covid-19 Community Language Project: Enhancing Collaborations between the University and Schools in Rembau, Negeri Sembilan
}

Norwati Roslim, Muhammad Hakimi Tew Abdullah, Nur Faathinah Mohammad Roshdan, Siti 'Aishatul-Humairah Muhammad Fisol, Suhaila Sharil, Ku Nurul Atiqah Ku Ahamad, Zoe Lee Hui Hui

To Link this Article: http://dx.doi.org/10.6007/IJARBSS/v11-i11/11533

DOI:10.6007/IJARBSS/v11-i11/11533

Received: 05 September 2021, Revised: 28 September 2021, Accepted: 19 October 2021

Published Online: 04 November 2021

In-Text Citation: (Roslim et al., 2021)

To Cite this Article: Roslim, N., Abdullah, M. H. T., Roshdan, N. F. M., Fisol, S. 'Aishatul-H. M., Sharil, S., Ahamad, K. N. A. K., \& Hui, Z. L. H. (2021). Covid-19 Community Language Project: Enhancing Collaborations between the University and Schools in Rembau, Negeri Sembilan. International Journal of Academic Research in Business and Social Sciences, 11(11), $391-400$.

\section{Copyright: (c) 2021 The Author(s)}

Published by Human Resource Management Academic Research Society (www.hrmars.com)

This article is published under the Creative Commons Attribution (CC BY 4.0) license. Anyone may reproduce, distribute, translate and create derivative works of this article (for both commercial and non-commercial purposes), subject to full attribution to the original publication and authors. The full terms of this license may be seen at: http://creativecommons.org/licences/by/4.0/legalcode

Vol. 11, No. 11, 2021, Pg. $391-400$ 


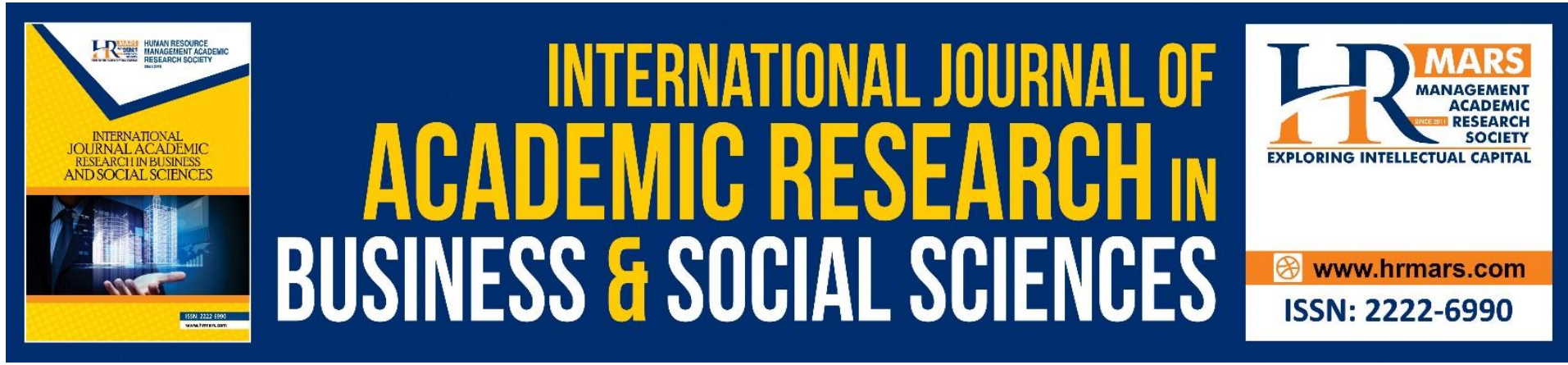

\title{
Covid-19 Community Language Project: Enhancing Collaborations between the University and Schools in Rembau, Negeri Sembilan
}

\author{
Norwati Roslim¹, Muhammad Hakimi Tew Abdullah², Nur \\ Faathinah Mohammad Roshdan ${ }^{1}$, Siti 'Aishatul-Humairah \\ Muhammad Fisol ${ }^{1}$, Suhaila Sharil ${ }^{3}$, Ku Nurul Atiqah Ku \\ Ahamad $^{2}$, Zoe Lee Hui Hui ${ }^{4}$
}

${ }^{1}$ Academy of Language Studies, Universiti Teknologi MARA, Cawangan Negeri Sembilan, Kampus Rembau, ${ }^{2}$ Faculty of Communication and Media Studies, Universiti Teknologi MARA, Cawangan Negeri Sembilan, Kampus Rembau, ${ }^{3}$ Academy of Contemporary and Islamic Studies, Universiti Teknologi MARA, Cawangan Negeri Sembilan, Kampus Rembau.

${ }^{4}$ Khind Starfish Foundation

Email:norwati@uitm.edu.my

\begin{abstract}
Universiti Teknologi MARA (UiTM), Cawangan Negeri Sembilan, Kampus Rembau has made a huge initiative to ensure the continuity of education through community projects during the Covid-19 crisis. Recently, a collaborative community project between the university and two primary schools in Rembau district area has been initiated to increase community awareness on the importance of English language learning. An introduction of a community innovative project called, "Language Café" which is an English language project aims to support the use of English language among university students and school students. This project is specifically designed to accommodate the Covid-19 environment and enhance the collaborations between the university and schools. The development of teaching and learning materials as well as the training modules serve as tools for university students to implement community projects with the schools.
\end{abstract}

Keywords: Covid-19, Community Language Project, Collaborations, Modules

\section{Introduction}

Due to Covid-19, community projects that rely on face-to-face meetings have been affected tremendously and can be absolutely challenging. Despite the uncertainty of the Covid-19 situation, this challenging situation has provided a unique opportunity in the field of education. At a university level, university students are highly encouraged to volunteer in community projects. Active participants can help to boost self-confidence and can give the opportunity to develop social skills (Segal and \& Robinson, 2019) and soft skills of students in institutions of higher education (Harun \& Salamuddin, 2013). University students have 
frequently become facilitators for community projects related to providing education for the community and they are commonly guided and advised by a group of lecturers (Abd Aziz et al., 2020).

In support of this, the Covid-19 crisis is seen as an opportunity for promoting education in terms of online teaching and learning (Kamal et al., \& Junaini, 2020; Abdullah et al., 2020). Hence, university students' facilitators for community projects need to be equipped with various teaching and learning modes (Kamal et al., 2020), for instance through media social (Instagram, Facebook, Whatsapp, Telegram), live video conferences (Zoom, Microsoft Teams, Google Meet, Webex) as well as pre-recorded lecture videos such as on YouTube. These are essential technology platforms in managing community projects updates.

Universiti Teknologi MARA (UiTM) Cawangan Negeri Sembilan, Kampus Rembau has taken a major role to demonstrate the important role of higher education for the community. Collaborative efforts between the university and the community have shown an engagement in outreach activities to help the community during this difficult time of Covid-19. The need to sustain and increase community awareness on education is essentially required to ensure its continuity. A proper planning has to be developed carefully due to the transition from a traditional face-to-face approach to the current challenging situation of online teaching and learning.

Previous studies have identified challenges of online learning. These include technological challenges, pedagogical challenges and social challenges. Ferri et al (2020) summarized some key obstacles to the effective use of online learning identified in the literature. Firstly, technological challenges are described as "Access to infrastructure such as technological devices and an Internet connection". Secondly, pedagogical challenges mean "Teachers' lack of skills in using technology... Need for teaching materials in the form of interactive multimedia... Lack of student feedback and evaluation system". Thirdly, social challenges highlight "Lack of suitable home learning environment to study and parents' support".

Similarly, Lukas and Yunus (2021); Wen and Kim (2020) describe the issue in relation to Malaysia. These obstacles really challenge the teaching and learning of English language for Second Language Learners in rural areas in Malaysia. The need to assist these learners especially among the primary school students is crucial. To overcome these difficulties, Yusuf and Jihan (2020) suggests that an increase access to the Internet needs to be provided and the need to develop an interactive learning approach. Moreover, it is necessary to provide workshops or trainings to improve technological and pedagogical competencies in online learning.

Hence, in view of these challenges, this paper attempts to describe a project on English language and explains the details of the project materials and training modules as a model for Covid-19 Community Language Project.

\section{Problem Statement}

Research has shown challenges in education for online teaching and learning (Ferri et al., 2020; Lukas \& Yunus, 2021; Wen \& Kim, 2020; Yusuf \& Jihan, 2020) and benefits of community projects have been provided in many research (Abd Aziz et al., 2020; Abdullah et al., 2020; Harun \& Salamuddin, 2013; Kamal et al., 2020; Segal \& Robinson, 2019). However, English language modules for community language projects at the times of Covid-19 have not been clearly portrayed in the literature as to date even though attempts to provide examples of resources to support student learning in the time of Covid-19 have been made by many. Consequently, this makes it difficult for university lecturers who have been guiding and 
advising university students' to continue their efforts to provide education for the community especially for the schools in the rural district area. In response to this issue, the aim of this paper is to present the materials development and training modules for community language project to assist the university and schools in enhancing their collaborations.

\section{Research Objectives}

The research objectives of this study are as follows:

1. To describe the materials development modules for university and school community language project.

2. To explain the training session modules for university and school community language project.

\section{Methodology}

An innovative community language project entitled "Language Café" project was inspired by the previous English Language: Grammar Learning Adventures (G.L.A.D.) which was successfully conducted before the COVID-19 pandemic by Universiti Teknologi MARA (UiTM) Cawangan Negeri Sembilan, Kampus Rembau. "Language Café" project was designed to increase community awareness on the importance of English language learning during Covid19 crisis. It was developed collaboratively by four university lecturers as advisors and trainers and was then implemented by 12 university students as facilitators. Primary school students aged between 10 and 12 years old from two selected schools at a rural area participated in the implementation of "Language Café" project with full support from the principals and Parents and Teachers' Association of the respective schools.

Communications with the principals from each school were conducted online through Google Meet, WhatsApp and phone calls to gain permission for the project. Discussions on the school students' participation and learning modes with the students were also carried out with the principals. The parents were then informed by the schools for the participation consent of their children. "Language Café" project was well-received by the schools' community through its cooperation in permitting the school students to participate in the project. A list of students was provided to attend this project as participants and these students were set in small groups by the schools. Essentially, this project was considered relevant to meet the community needs. A formal university-community cooperation agreement was set up to generally agree on the implementation of the project.

Due to the Covid-19 restrictive measures, this project was conducted online and the monitoring was under the guidance of the lecturers and university students volunteers. However, the primary school students were also given the printed language learning materials for them to be able to do the activities offline if there was an online connection problem. The printed modules were placed at their schools for collection and the online modules produced by the English language lecturers were shared with the students via WhatsApp groups and Telegram groups between 1st September and 1st October, 2021.

\section{Results}

The results are presented based on the research objectives.

Research objective 1: To describe the materials development modules for university and school community language project. 
The materials specifically designed for "Language Café" project were Module 1 - Language Café: Workbook, Module 2 - Language Café: Games and Module 3 - Language Café: A Handbook for Trainers.

\section{Module 1 - Language Café: Workbook}

This module consists of a description on each part of speech with examples and exercises. Each part of speech is arranged according to units and exercises. The parts of speech presented in this module are noun, pronoun, verb, adverb, adjective, article, preposition and conjunction.

\section{Module 2 - Language Café: Games}

This module contains a set of board games, dice, movers and question cards to enhance the use of parts of speech based on the units in Module 1 - Language Café: Workbook. Each card consists of one question on each part of speech. There are three questions prepared for each part of speech.

\section{Module 3 - Language Café: A Handbook for Trainers}

This module presents a step-by-step approach for trainers to conduct Module 1 - Language Café: Workbook and Module 2 - Language Café: Games. It highlights the four steps of the Training Procedures. They are Step 1: Set the scene, Step 2: Set the schedule, Step 3: Model the activity and Step 4: Attendance sheet and remarks.

Research objective 2: To explain the training session modules for university and school community project.

Module 3 - Language Café: A Handbook for Trainers was purposely produced by the English language lecturers who became the advisors and trainers for this project. Their roles were to assist and train the university students in conducting the project based on the modules provided. The university students who became the facilitators then conducted the "Language Café" project modules to the participated schools according to their respective small groups which consisted of 10 participants each.

There were four steps in the training procedures:

Step 1: Set the scene

a. Each facilitator receives Module 3 - Language Café: A Handbook for Trainers.

b. Each facilitator sets the scene of the activity using WhatsApp, Telegram or Google Meet, whichever platform is convenient.

Step 2: Set the schedule

c. Each facilitator sets the scheduled date and time for each group assigned for them. The availability of school students to participate according to the schedule was discussed and negotiated to reach to an agreement.

Step 3: Model the activity

d. Each university facilitator models how activities in Module 1 - Language Café: Workbook and Module 2 - Language Café: Games to be conducted. Instructions for activities are as follows 
Module 1 - Language Café: Workbook

How to use the workbook:

1. Each student receives one workbook.

2. Each student write their details in the workbook.

3. Students are taught each part of speech e.g. Unit 1: Noun.

4. This is followed by an exercise to be completed for each unit.

5. Answers are discussed and recorded.

6. Upon completion of the workbook, each student writes their name on a certificate of completion provided on the last page of the workbook.

Module 2: Language Café: Games

How to play the game

1. Each student receives a set of board games, dice, movers and question cards and becomes the player.

2. Each player puts their mover on the space that says "START".

3. Each player takes a turn to roll the dice.

4. Each player moves the mover forward the number of spaces shown on the dice.

5. If the mover lands at a note that says 'ANSWER THE QUESTION', the player will need to answer the question from a card read by another player.

6. If the answer is correct, the player will move forward one space.

7. If the answer is incorrect, the player will have to move backward one space.

8. The first player to get to the space that says "FINISH", is the winner.

Step 4: Attendance sheet and remarks

e. Each facilitator records the attendance and remarks for each group assigned for them. The details of the materials and training modules are shown in Table 1. 
Table 1. Materials and Training Modules

\begin{tabular}{|c|c|c|}
\hline MATERIALS & CONTENTS & INSTRUCTIONS \\
\hline $\begin{array}{l}\text { Module 1: Language Café: } \\
\text { Workbook }\end{array}$ & $\begin{array}{l}\text { A description on each part of } \\
\text { speech with examples and } \\
\text { exercises. } \\
\text { Unit 1: Noun } \\
\text { Unit 2: Pronoun } \\
\text { Unit 3: Verb } \\
\text { Unit 4: Adverb } \\
\text { Unit 5: Adjective } \\
\text { Unit 6: Article } \\
\text { Unit 7: Preposition } \\
\text { Unit 8: Conjunction }\end{array}$ & $\begin{array}{l}\text { How to use the workbook: } \\
\text { 1. Each student receives one } \\
\text { workbook. } \\
\text { 2. Each student writes their } \\
\text { details in the workbook. } \\
\text { 3. Students are taught each } \\
\text { part of speech e.g. Unit } 1 \text { : } \\
\text { Noun. } \\
\text { 4. This is followed by an } \\
\text { exercise to be completed for } \\
\text { each unit. } \\
\text { 5. Answers are discussed } \\
\text { and recorded. } \\
6 \text {. Upon completion of the } \\
\text { workbook, each student } \\
\text { writes their name on a } \\
\text { certificate of completion } \\
\text { provided on the last page of } \\
\text { the workbook. }\end{array}$ \\
\hline
\end{tabular}

Module 2: Language Café: A set of board games, dice, Games

movers and question cards to enhance the use of parts of speech based on the units in Module 1: Language Café: Workbook

Unit 1: Noun

Unit 2: Pronoun

Unit 3: Verb

Unit 4: Adverb

Unit 5: Adjective

Unit 6: Article

Unit 7: Preposition

Unit 8: Conjunction
How to play the game:

1. Each student receives one set of board game and question cards with movers and a dice and become the player.

2. Each player puts their mover on the space that says "START".

3. Each player takes a turn to roll the dice.

4. Each player moves the mover forward the number of spaces shown on the dice. 5. If the mover lands at a note that says 'ANSWER THE QUESTION', the player will need to answer the question from a card read by another player.

6. If the answer is correct, the player will move forward one space. 
7. If the answer is incorrect, the player will have to move backward one space.

8. The first player to get to the space that says "FINISH", is the winner.

Module 3: Language Café: A A step-by-step approach for Handbook for Trainers trainers to conduct Module 1: Language Café: Workbook and Module 2: Language Café: Games. Training Procedure: Step 1: Set the scene Step 2: Set the schedule Step 3: Model the activity Step 4: Attendance sheet and remarks
How to use the handbook:

1. Each facilitator receives Module 3 - Language Café: A Handbook for Trainers.

2. Each facilitator sets the scene of the activity using WhatsApp, Telegram or Google Meet, whichever platform is convenient.

3. Each facilitator sets the scheduled date and time for each group assigned for them. The availability of school students to participate according to the schedule was discussed and negotiated to reach to an agreement.

4. Each university facilitator models how activities in Module 1 - Language Café: Workbook and Module 2 Language Café: Games to be conducted.

5. Each facilitator records the attendance and remarks for each group assigned for them.

\section{Discussion}

Covid 19 has demonstrated the need to continue participation and collaboration between the university and community through materials and training modules. These modules could be used as tools for community language projects during the crisis.

However, online feature of the project is the major limitation. Obstacles faced are due to the existing limitations related to technological, pedagogical and social challenges (Ferri et al., 2020). Modules development, modules delivery, training sessions and online teaching and learning sessions pose challenges to the project. 
Teaching and learning modules were prepared via Google Meet and were revised several times during the meetings with regard to the contents and designs to ensure accuracy and error-free. Modules were prepared in both printed and online versions. They were sent for printings, then, packed and delivered to university students' facilitators via postage. For school participants, printed and packed materials were placed at the school post-guard for collection by parents of the school participants.

Training sessions between the module developers and university student facilitators were conducted through Google Meet. Module developers train the student facilitators using both printed and online versions as a preparation for online teaching and learning with the school participants. Student facilitators set schedules with their respective groups of school participants and conducted the online teaching and learning until they completed the modules provided through Google Meet, WhatsApp and Telegrams.

School students used the printed modules they received for the project and attended the teaching and learning sessions online conducted by the university student facilitators. However, due to internet interruptions and lack of technology facilities such as sharing of smart phones and computers with family members for school students' participants in rural area, they were unable to fully join the learning sessions even though agreements for the scheduled date and time had been made. This challenge has been tackled by allowing the school students to do the activities offline using the printed materials provided for them.

Hence, based on the materials and training modules provided and the various limitations encountered, it is recommended that more collaboration and innovation between university and schools could be developed to optimise the continuity of education during this critical period of Covid-19.

\section{Conclusion}

It can be concluded that this research theoretically contributes a basis for enriching knowledge by providing comprehensible input through the development of teaching and learning materials and modules. These materials and modules which are in line with their pedagogical goals have been designed in a way that lower the affective filter and motivate the students to learn. Collaborations among the university and schools in enriching knowledge and ensuring the continuity of education between them at a time of global challenge promotes a significant learning environment and reinforce the linkages in the community.

\section{Acknowledgements}

The authors gratefully acknowledge the support given by Universiti Teknologi MARA (UiTM), Cawangan Negeri Sembilan and KHIND Starfish Foundation for funding this community project (Project Number: PFH21-59 Language Café). Also, special thanks to the schools, parents and community of Rembau, Negeri Sembilan for their tremendous support throughout the collaborations between the university and schools.

\section{Corresponding Author}

Associate Professor Dr Norwati Binti Haji Roslim, Academy of Language Studies, Universiti Teknologi MARA, Cawangan Negeri Sembilan, Kampus Rembau, Jalan Pilin, 71300Rembau, Negeri Sembilan, Malaysia.

Email:norwati@uitm.edu.my 


\section{References}

Abd Aziz, A. S., Nor, C. M. R., \& Sahmat, S. S. (2020). Students' Perception and the Effectiveness of Corporate Social Responsibility among UiTM Sarawak Branch. Jurnal Penyelidikan Sains Sosial (JOSSR), 3(7), 45 - 55.

Abdullah, J. M., Ismail, W. F. N. M. W., Mohamad, I., Ab Razak, A., Harun, A., Musa, K. I., \& Lee, Y. Y. (2020). A Critical Appraisal of COVID-19 in Malaysia and Beyond. The Malaysian Journal of Medical Sciences: MJMS, 27(2), 1.

Ferri, F., Grifoni, P., \& Guzzo, T. (2020). Online Learning and Emergency Remote Teaching: Opportunities and Challenges in Emergency Situations. Societies, 10(4), 86.

Harun, M. T., \& Salamuddin, N. (2013). Applying Elements of Outdoor Education in Teacher Education Innovation. Asian Social Science, 9(16), 15.

Kamal, A. A., Shaipullah, N. M., Truna, L., Sabri, M., \& Junaini, S. N. (2020). Transitioning to Online Learning during COVID-19 Pandemic: Case study of a Pre-University Centre in Malaysia. International Journal of Advanced Computer Science and Applications, 11(6).

Lukas, B. A., \& Yunus, M. M. (2021). ESL Teachers' Challenges in Implementing E-learning during COVID-19. International Journal of Learning, Teaching and Educational Research, 20(2), 330- 348.

Wen, K. Y. K., \& Kim, H. T. (2020). ESL Teachers' Intention in Adopting Online Educational Technologies during COVID-19 Pandemic. Journal of Education and ELearning Research, 7(4), 387-394.

Yusuf, B. N., \& Jihan, A. (2020). Are we prepared enough? A Case Study of Challenges in Online Learning in a Private Higher Learning Institution during the Covid-19 Outbreaks. Advances in Social Sciences Research Journal, 7(5), 205-212. 